\title{
Role of dopaminergic system in oxytocin analgesia: The missing part in a puzzle
}

\author{
Yaşar Taştemur ${ }^{1}$, Ahmet Şevki Taşkıran ${ }^{2 *}$, Ahmet Altun ${ }^{3}$, Ahmet Kemal Filiz², \\ Kader Gülmez², Kaan Çimen ${ }^{1}$, Ercan Özdemir ${ }^{2}$ \\ ${ }^{1}$ Department of Anatomy, ${ }^{2}$ Department of Physiology, ${ }^{3}$ Department of Pharmacology, Cumhuriyet University Medical Faculty, \\ Sivas, Turkey \\ *For correspondence: Email: ahmettaskiran@cumhuriyet.edu.tr; Tel: +90 346219 1010; Fax: +90 3462191602
}

\begin{abstract}
Purpose: To investigate the analgesic effects of oxytocin (OT) and elucidate the role of dopaminergic system in its mechanisms.

Methods: In this study, 72 male (n=6 for each group) 230-250 gr Wistar Albino rats were used. Firstly, dose studies were performed with $100 \mu \mathrm{g} / \mathrm{kg}, 200 \mu \mathrm{g} / \mathrm{kg}$ and $400 \mu \mathrm{g} / \mathrm{kg}$ to determine the optimal analgesic effect of oxytocin. Optimal dose was found at $200 \mu \mathrm{g} / \mathrm{kg}$, and then animals were divided into nine groups: Saline, D1 agonist (SKF 38393; $0.1 \mathrm{mg} / \mathrm{kg}$ ), D1 antagonist (SCH-23390; $0.1 \mathrm{mg} / \mathrm{kg}), D 1$ agonist + oxytocin, D1 antagonist + oxytocin, D2 agonist (Cabergoline; 0,5 mg/kg), D2 antagonist (Sulpride; $10 \mathrm{mg} / \mathrm{kg}$ ), D2 agonist + oxytocin and D2 antagonist + oxytocin. Serum physiologic saline was given to the saline group and other drugs were administered intraperitoneally at the indicated doses. Tail-flick and hot-plate tests were used to measure analgesic effects. Analgesic tests were measured in 30 min-intervals (at 30th, 60th, 90th, and 120th $\mathrm{min}$ ) and recorded in seconds. To evaluate maximum antinociceptive effect (\% MPE), the tail-flick and hot-plate latencies were converted to the antinociceptive effectiveness

Results: The results show that D1 antagonist $\mathrm{SCH}-23390(0.1 \mathrm{mg} / \mathrm{kg})$ and D2 agonist cabergoline $(0.5$ $\mathrm{mg} / \mathrm{kg}$ ) created strong analgesia while the D1 agonist SKF $38393(0.1 \mathrm{mg} / \mathrm{kg})$ and D2 antagonist sulpiride $(10 \mathrm{mg} / \mathrm{kg})$ did not have any analgesic effect. However, only D2 antagonist sulpiride blocked the analgesic effect produced by OT

Conclusion: OT may be one of the primary agents participating in spinal analgesia, and the dopaminergic system is one of the central mechanisms of action for this important molecule. The dopaminergic system may also be one of the targets for 'descending' analgesic system.
\end{abstract}

Keywords: Oxytocin, Tail flick, Hot plate, Dopaminergic, Analgesic, Antagonist, Agonist

\begin{abstract}
This is an Open Access article that uses a fund-ing model which does not charge readers or their institutions for access and distributed under the terms of the Creative Commons Attribution License (http://creativecommons.org/licenses/by/4.0) and the Budapest Open Access Initiative (http://www.budapestopenaccessinitiative.org/read), which permit unrestricted use, distribution, and reproduction in any medium, provided the original work is properly credited.

Tropical Journal of Pharmaceutical Research is indexed by Science Citation Index (SciSearch), Scopus, International Pharmaceutical Abstract, Chemical Abstracts, Embase, Index Copernicus, EBSCO, African Index Medicus, JournalSeek, Journal Citation Reports/Science Edition, Directory of Open Access Journals (DOAJ), African Journal Online, Bioline International, Open-J-Gate and Pharmacy Abstracts
\end{abstract}

\section{INTRODUCTION}

Oxytocin (OT) is an amine peptide synthesized in the paraventricular (PVN) and the supraoptic (SO) nuclei of the hypothalamus. OT is released from the posterior pituitary into the systemic circulation, where it plays a fundamental role in mammalian labor and lactation through its peripheral actions [1], and modulates numerous functions including maternal bonding and social 
affiliation through its central actions [2,3]. Recently, the effect of OT on pain sensitivity in both humans and animals has been increasingly investigated by several research groups, including ours.

The first important mechanism linking OT and pain involves hypothalamospinal oxytocinergic pathways. Stimulation of the PVN or administration of OT activates presynaptic OT receptors (OTRs) located superficially in the dorsal horn (Laminae I and II), which subsequently excites inhibitory GABAergic interneurons. Activation of GABAergic interneurons, in turn, pre-synaptically inhibits $A$ Delta fiber and $C$ fiber signals at nociceptivespecific and wide-dynamic-range neurons in Laminae I and II [4-6]. These effects can be reversed by selective OTR antagonists (d(CH2)5[Tyr(Me), Thr, Tyr-NH29]OVT) [7].

The second potential mechanism linking OT and pain involves an indirect pathway through the endogenous opioid system. Injection of opioid receptor (OR) antagonists has been reported to partially block the analgesic effects of OT. Regarding the relationship between OT and endogenous opiates, at least two potential mechanisms exist: OT can stimulate the release of endogenous opioids in the brain [8,9], and OT can bind to ORs and act as an orthosteric agonist or an allosteric modulator.

Dopamine (DA) is a catecholamine neurotransmitter best known for its role in movement, cognition, and reward. However, the role of DA in nociception has been addressed in different basic and clinical studies [10]. Dopaminergic innervations inside the CNS arise from substantia nigra (SN), ventral tegmental area (VTA), and hypothalamus and reach numerous supraspinal structures and also areas in the SC $[10,11]$. In the basal ganglia, stimulation of mesolimbic dopaminergic neurons in the nucleus accumbens (NAc) and ventral striatum, either pharmacologically or provoked by stress conditions, has shown an analgesic effect. This effect appears to be mediated by D2 receptors as D2 agonist strengthens it and is blocked by a specific D2 antagonist eticlopride; D1 receptors did not show a related activity [12].

Additionally, microinjection of D2 agonist (quinpirole) in NAc inhibits the persistent phase of formalin-induced nociception in a dosedependent manner [13]. Stimulation of VTA/SN has demonstrated an analgesic effect against chronic pain [14]. In Parkinson disease (PD), where there is a disruption in DA transmission, clinical evidence shows a close relation between pain-related symptoms and DA depletion [15]. Pain thresholds (heat and cold thresholds) are reduced in PD patients; this effect is reversed by L-DOPA administration [16].

Although the participation of the dopaminergic system in nociception is well documented over the years, there is however only one study that tried to a build a hypothesis to explain the involvement of the dopaminergic system in OT analgesia.

In the present study, we aimed to investigate the relationship between OT analgesia and the dopaminergic system, and provide more details on the mechanism of action of OT.

\section{EXPERIMENTAL}

\section{Animals}

The experiments were performed using adult male Wistar rats weighing $230-250 \mathrm{~g}(\mathrm{n}=72)$. The animals were fed a standard laboratory diet and water ad libitum, kept at $22 \pm 2{ }^{\circ} \mathrm{C}$ with a 12 $\mathrm{h}$ light/dark cycle in a closed room, which had a lighting system controlled by timers. Animals were acclimatized to laboratory conditions before the test. All experiments were carried out blindly between 09:00 and 17:00 h $(n=6$ in each experimental group in the study). The Cumhuriyet University Animal Ethics Committee approved the experimental protocols (approval no. 65202830-050.04.04).

\section{Experimental protocol}

At the beginning of the study, the anti-nociceptive effect of 100,200 and $400 \mu \mathrm{g} / \mathrm{kg}$ in $1 \mathrm{ml} / \mathrm{kg}$ serum physiologic OT was given intraperitoneally (i.p.) to determine the optimal dose of the OT for further experimentation. Optimal dose was found at $200 \mu \mathrm{g} / \mathrm{kg}$ and then animals were divided into nine groups: saline, D1 agonist (SKF 38393; 0.1 $\mathrm{mg} / \mathrm{kg}$ ), D1 antagonist (SCH-23390; $0.1 \mathrm{mg} / \mathrm{kg})$, D1 agonist + oxytocin, D1 antagonist + oxytocin, D2 agonist (Cabergoline; 0,5 $\mathrm{mg} / \mathrm{kg}$ ), D2 antagonist (Sulpride; $10 \mathrm{mg} / \mathrm{kg}$ ), D2 agonist + oxytocin and D2 antagonist + oxytocin. Serum physiologic was given to the saline group i.p.; other drugs were dissolved in serum physiologic and were administered i.p. at the indicated doses. Tail-flick and hot-plate tests were used to measure analgesic effects. Analgesic tests were measured at 30 min-intervals (at 30th, 60th, 90th, and 120th minutes) and recorded in seconds. In order to evaluate the percentages of maximum antinociceptive effect (\% MPE), the tail-flick and hot-plate latencies were converted to $\%$ MPE. 


\section{Tail-flick test}

We used a standardized tail flick apparatus (May TF 0703 Tail-flick Unit, Commat, Turkey) to evaluate thermal nociception. The radiant heat source was focused on the distal portion of the tail at $3 \mathrm{~cm}$ after administration of the vehicle or study drugs intraperitoneally. Following vehicle or compound administration, tail-flick latencies (TFL) were obtained. The infrared intensity was adjusted so that basal TFL occurred at $2.8 \pm 0.4$ second. Animals with a baseline TFL below 2.4 or above $3.2 \mathrm{~s}$ were excluded from further testing. The cutoff latency was set at $15 \mathrm{~s}$ to avoid tissue damage. Any animal not responding after $15 \mathrm{~s}$ was excluded from the study. The analgesic response in the tail-flick test is generally attributed to central mechanisms $[21,22]$.

\section{Hot-plate test}

The antinociceptive response on the hot-plate is considered to result from a combination of central and peripheral mechanisms [22]. In this test, animals were individually placed on a hotplate (Eddy's Hot-Plate) with the temperature adjusted to $55 \pm 1^{\circ} \mathrm{C}$. The latency to the first sign of paw licking or jump response to avoid the heat was taken as an index of the pain threshold; the cut-off time was $30 \mathrm{~s}$ to avoid damage to paws.

\section{Data analysis}

The maximum possible effect ( $\%$ MPE) was calculated for each rat at each dose and time point according to Eq 1 .

$\operatorname{MPE}(\%)=\{(P-B / C-B)\} 100$

where $\mathrm{P}, \mathrm{B}$ and $\mathrm{C}$ are post-latency, baseline latency and cutoff latency, respectively.

\section{Statistical analysis}

The results obtained are expressed as mean \pm SEM (standard error of the mean). The effect of anti-nociception was measured, and the mean of $\%$ MPEs in all groups was calculated. The data was analyzed by analysis of variance followed by the Tukey test. $P<0.05$ was considered significant.

\section{RESULTS}

\section{Analgesic effect of oxytocin (dose trial)}

Even though the analgesic effect of oxytocin has been already successfully shown in literature, we needed to conduct a dosing trial to decide which doses of oxytocin we have to use for experimental setup. After preliminary studies, we narrowed the range between 100 and $400 \mu \mathrm{g} / \mathrm{kg}$. Oxytocin created time and dose-dependent analgesic effects for all doses, both in the tail flick and hot plate tests. There was a significant difference between 100 and $200 \mu \mathrm{g} / \mathrm{kg}$ regarding the analgesic effect $(p<0.05)$. The dose of 200 $\mu \mathrm{g} / \mathrm{kg}$ created a significantly higher analgesic effect when compared to $100 \mu \mathrm{g} / \mathrm{kg}$. Nevertheless, there was no significant difference between the 200 and $400 \mu \mathrm{g} / \mathrm{kg}$ dose $(p<0.05)$. Hence $200 \mu \mathrm{g} / \mathrm{kg}$ was chosen for the rest of the experiments as the submaximal dose to be used (Figure $1 \mathrm{~A}$ and $\mathrm{B}$ ).

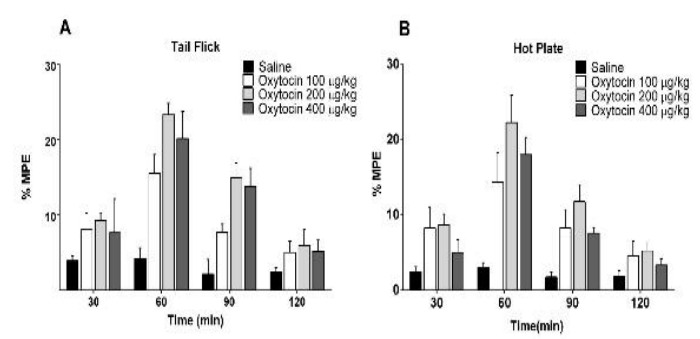

Figure 1: A) Tail flick latencies of 100, 200, and 400 $\mu \mathrm{g} / \mathrm{kg}$ oxytocin; B) hot plate latencies of 100,200 , and $400 \mu \mathrm{g} / \mathrm{kg}$ oxytocin

\section{Role of D1 receptors in analgesic effect of oxytocin}

The analgesic effect of oxytocin has been reevaluated in the presence of D1 and D2 receptor agonist and antagonist to elucidate the role of the dopaminergic system in the analgesic effect of oxytocin.

Administration of D1 agonist alone did not create any algesic and analgesic effects. Furthermore, it did not have any effect on the analgesic effect of oxytocin. Both the tail flick and hot plate latencies were unchanged (same level) following the administration of oxytocin alone. On the contrary, administration of D1 agonist and D1 antagonist created a strong, time-dependent analgesic effect. However, the D1 antagonist had no effect on the analgesic effect of oxytocin (Figure $2 \mathrm{~A}$ and $B$, Figure $3 \mathrm{~A}$ and $\mathrm{B}$ ).

\section{Role of D2 receptors in Analgesic effect of Oxytocin}

Administration of D2 agonist alone created a time-dependent analgesic effect similar to the D1 antagonist. On the other hand, the analgesic effect of oxytocin did not change in the presence of D2 agonist, and while D2 antagonist alone did not have any algesic or analgesic effect, it did 
however reduce the analgesic effect of oxytocin significantly $(p<0.05)$.

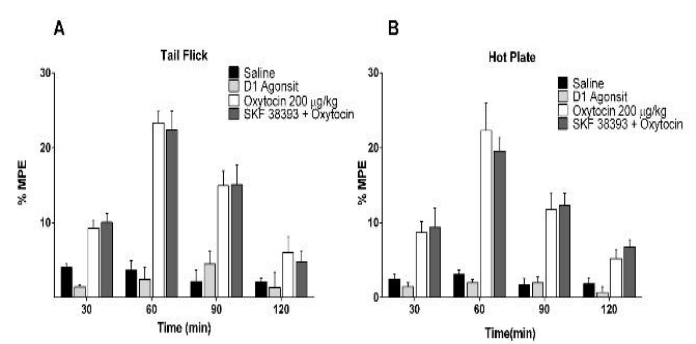

Figure 2: A) Tail Flick Latencies of $200 \mu \mathrm{g} / \mathrm{kg}$ Oxytocin in the Presence of D1 Agonist, B) Hot Plate Latencies of $200 \mu \mathrm{g} / \mathrm{kg}$ Oxytocin in the Presence of D1 Agonist

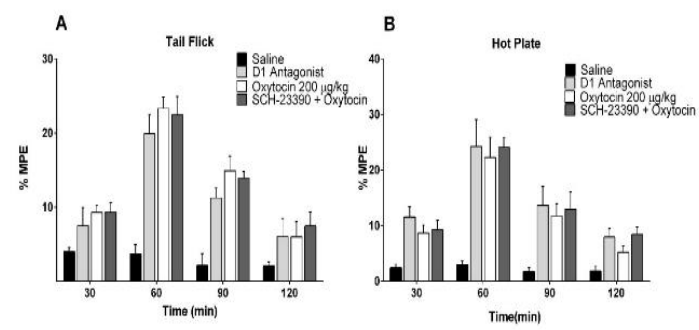

Figure 3: A) Tail Flick Latencies of $200 \mu \mathrm{g} / \mathrm{kg}$ oxytocin in the presence of D1 antagonist, B) hot plate latencies of $200 \mu \mathrm{g} / \mathrm{kg}$ Oxytocin in the presence of D1 antagonist

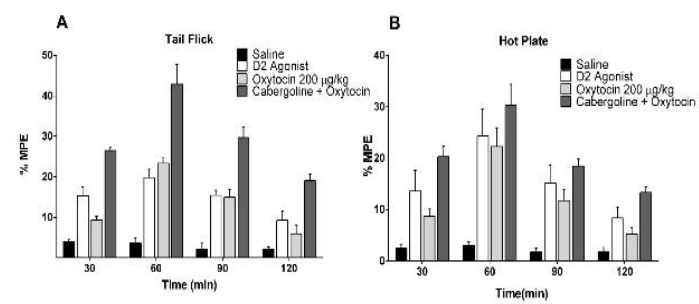

Figure 4: A) Tail Flick Latencies of $200 \mu \mathrm{g} / \mathrm{kg}$ Oxytocin in the Presence of D2 Agonist cabergoline, B) Hot Plate Latencies of $200 \mu \mathrm{g} / \mathrm{kg}$ Oxytocin in the Presence of D2 Agonist cabergoline

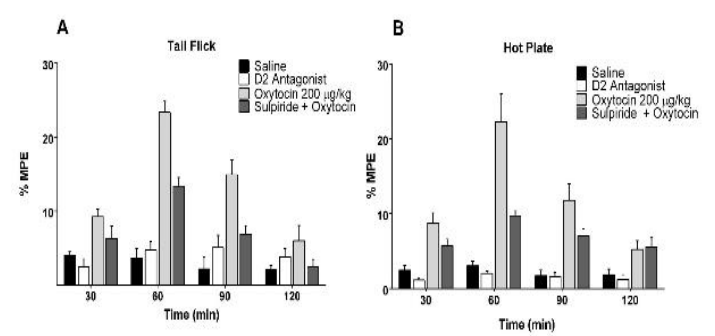

Figure 5: A) Tail Flick Latencies of $200 \mu \mathrm{g} / \mathrm{kg}$ Oxytocin in the Presence of D2 Antagonist, B) Hot Plate Latencies of $200 \mu \mathrm{g} / \mathrm{kg}$ Oxytocin in the Presence of D2 Antagonist

\section{DISCUSSION}

Oxytocin is a peptide produced in the paraventricular nucleus of the hypothalamus and associated with many important biological functions [17]. Recent studies have demonstrated the involvement of oxytocin in the modulation of nociception [18]. The emerging roles of oxytocin as an endogenous and exogenous analgesic have been reported in several clinical reports and basic researches using animal models [19]. In our study, consistent with literature $[4,6,8]$, we demonstrated the analgesic effects of oxytocin in acute pain models. We also showed the optimal dose of oxytocin, which was also similar to the doses used in the studies in literature. Although all literature $[4,6,8]$ is in agreement on the nociceptive effect of oxytocin, the mechanism for this action is still unclear. Currently, it is known that OT is able to reduce pain transmission by activation of several pathways. At spinal levels, OT enhances a-amino-3-hydroxy-5-methyl-4isoxazolepropionic acid (GABA) release from spinal interneurons [20] located in the substantial gelatinousa [21].

Furthermore, OT reduces the GABA-evoked $\mathrm{Ca}^{2+}$ transients in trigeminal nociceptive neurons [22]. It is well known that oxytocin receptors (OTRs) and vasopressin 1a receptors (V1aRs) are structurally very similar receptors, and at certain locations, one agonist for each of them can easily affect the other and create a biological signal. However in small- and medium-sized dorsal root ganglion (DRG) neurons, the OTinduced inhibition of intracellular $\mathrm{Ca}^{2+}$ currents can be prevented by OTR blockers, not V1aR blockers [23]. This finding shows that $\mathrm{V} 1 \mathrm{aRs}$ is one of the pathways for oxytocin to show its effects, but not the only one. Oxytocin also reinforces the GABAergic transmission (inhibition) in substancia gelatinosa via OTRs [21].

Qiu et al [24] suggest that peripheral OT can inhibit pain transmission at the periphery by activation of $\mathrm{V} 1 \mathrm{aR}$ which in turn shrink the activity of acid-sensing ion channels (ASIC). There are also studies mentioning the relationship between oxytocin analgesia and opioid system and mü receptors [25]. It is obvious that we have made progress in understanding the underlying mechanisms of oxytocin analgesia. Nevertheless, it is also clear that there is a missing part to the puzzle. In the present study, the role of the dopaminergic system in oxytocin analgesia has been investigated as that missing part in the puzzle. 
Dopamine has a role in both central and peripheral nociception. However, since exogenous oxytocin cannot pass the blood-brain barrier, the findings we had in our experimental set-up most likely were related to the peripheral nociception mechanism, most likely the spinal level. Dopamine-containing fibers and terminals are widely distributed in the spinal dorsal horn [26], which contains populations of both D1- and D2-class receptors [27]. It is shown that D1 receptor agonist did not have an affect, while D1 receptor antagonism induced the analgesic effect in an inflammatory pain model [28]. This is the same as our findings. In both tail flick and hot plate tests, we found that while D1 agonist did not affect algesia, D1 antagonist created a strong and time-dependent analgesic effect.

Furthermore, we showed that both D1 agonist and antagonist has no contribution in the analgesic effect of oxytocin, which indicates that D1 receptors do not take part in the mechanism of oxytocin-induced nociceptive effect. Liu et al [29] showed that Dopamine receptor D2, but not D1, mediates the descending dopaminergic pathway. This may be the reason D1 receptors are not participating in the analgesic effect of oxytocin. Hence since D1 receptors are coupled with the Gs/olf protein subunit of G-protein coupled receptors, inhibition of such a stimulating receptor would create inhibition in signaling, which in turn results in nociception. On the other hand, D2 receptors are coupled with the Gi/o protein subunit of G-protein coupled receptors [30].

Activation of spinal dopamine D2 receptors reduces pain-related behavioır following the establishment of inflammatory pain in both the affected and contralateral limb, while D2 receptor antagonism decreases pain thresholds [31]. Since D2 receptors are related to the descending nociceptive system, and they have an inhibitory nature. It should be expected that D2 agonists have an analgesic effect and D2 antagonists may reduce the analgesic effect created via D2 receptors. It was the case in our experimental design. We have shown that D2 agonist alone has a strong and time-dependent analgesic effect and the analgesic effect of oxytocin is prevented in the presence of D2 antagonist, which clearly indicates that oxytocin shows its analgesic effects at spinal level via D2 receptors. There may be more than one mechanism.

\section{CONCLUSION}

The dopaminergic system may have a more important role in the descending nociceptive pathways than it is thought. D2 receptors may mediate analgesic effects of many other molecules similar to the GABAergic system. To elucidate the mechanism of the analgesic effect of oxytocin and the role of the dopaminergic system at both spinal and central level, there is a need for further and advanced studies.

\section{DECLARATIONS}

\section{Conflict of interest}

No conflict of interest is associated with this work.

\section{Contribution of authors}

We declare that this work was done by the authors named in this article and all liabilities pertaining to claims relating to the content of this article will be borne by the authors.

\section{Open Access}

This is an Open Access article that uses a funding model which does not charge readers or their institutions for access and distributed under the terms of the Creative Commons Attribution License (http://creativecommons.org/licenses/by/ 4.0) and the Budapest Open Access Initiative (http://www.budapestopenaccessinitiative.org/rea d), which permit unrestricted use, distribution, and reproduction in any medium, provided the original work is properly credited.

\section{REFERENCES}

1. Kiss A, Mikkelsen JD. Oxytocin - Anatomy and functional assignments: A minireview. Endocr Regul 2005; 39: 97105

2. Higashida $H$, Lopatina $O$, Yoshihara $T$, Pichugina $Y A$, Soumarokov AA, Munesue T, Minabe Y, Kikuchi M, Ono $Y$, Korshunova $N$, Salmina $A B$. Oxytocin signal and social behaviour: Comparison among adult and infant oxytocin, oxytocin receptor and CD38 gene knockout mice. J Neuroendocrinol 2010; 22: 373-379.

3. Pedersen CA, Vadlamudi SV, Boccia ML, Amico JA. Maternal behavior deficits in nulliparous oxytocin knockout mice. Genes Brain Behav 2006; 5: 274-281.

4. Gerardo RP, Rosalinda MR, Guadalupe ML et al. Oxytocin, but not vassopressin, modulates nociceptive responses in dorsal horn neurons. Neurosci Lett 2010; 476:32-5.

5. Rojas-Piloni G, Mejía-Rodríguez R, Martínez-Lorenzana $G$, Condés-Lara M. Nociceptive spinothalamic tract and postsynaptic dorsal column neurons are modulated by paraventricular hypothalamic activation. Eur J Neurosci 2008; 28: 546-558.

Trop J Pharm Res, May 2020; 19(5): 1091 
6. Breton JD, Veinante $P$, Uhl-Bronner $S$, Vergnano $A M$, Freund-Mercier MJ, Schlichter R, Poisbeau P. Oxytocininduced antinociception in the spinal cord is mediated by a subpopulation of glutamatergic neurons in lamina I-II which amplify GABAergic inhibition. Mol Pain 2008; 29 : 4:19.

7. Condés-Lara M, Rojas-Piloni G, Martínez-Lorenzana G, Rodríguez-Jiménez J, López Hidalgo M, Freund-Mercier MJ. Paraventricular hypothalamic influences on spinal nociceptive processing. Brain Res 2006; 1081: 126137.

8. Yang J, Liang JY, Li P, Pan YJ, Qiu PY, Zhang J, Hao F, Wang DX. Oxytocin in the periaqueductal gray participates in pain modulation in the rat by influencing endogenous opiate peptides. Peptides 2011; 32: 12551261.

9. Csiffáry A, Ruttner Z, Tóth Z, Palkovits M. Oxytocin nerve fibers innervate $\beta$-endorphin neurons in the arcuate nucleus of the rat hypothalamus. Neuroendocrinology 1992; 56: 429-435.

10. Wood PB. Role of central dopamine in pain and analgesia. Expert Rev Neurother 2008; 8: 781-797.

11. Swanson LW, Kuypers HGJM. The paraventricular nucleus of the hypothalamus: Cytoarchitectonic subdivisions and organization of projections to the pituitary, dorsal vagal complex, and spinal cord as demonstrated by retrograde fluorescence double-labeling methods. J Comp Neurol 1980; 194: 555-570.

12. Altier N, Stewart J. The role of dopamine in the nucleus accumbens in analgesia. Life Sci 1999; 65: 2269-2287.

13. Taylor BK, Joshi C, Uppal H. Stimulation of dopamine D2 receptors in the nucleus accumbens inhibits inflammatory pain. Brain Res 2003; 987: 135-143.

14. Sotres-Bayón F(1), Torres-López E, López-Avila A, del Angel R, Pellicer F. Lesion and electrical stimulation of the ventral tegmental area modify persistent nociceptive behavior in the rat. Brain Res 2001; 898 (2): 342-349

15. Sophie M, Ford B. Management of Pain in Parkinson's Disease. CNS Drugs 2012; 26: 937-948.

16. Schestatsky P, Kumru H, Valls-Solé J, Valldeoriola $F$, Marti MJ, Tolosa E, Chaves ML. Neurophysiologic study of central pain in patients with Parkinson disease. Neurology 2007; 69: 2162-2169.

17. Zimmermann-Górska I, Bornakowska-Zabel E, Zabłotna O. Odległa obserwacja kliniczna rodziny $z$ agregacja zapalenia stawów i objawów pozastawowych. Reumatologia 2009; 47: 258-267.

18. González-Hernández A, Rojas-Piloni G, Condés-Lara M. Oxytocin and analgesia: Future trends. Trends Pharmacol Sci 2014; 35: 549-551.

19. Lundeberg T, Uvnäs-Moberg K, Agren G, Bruzelius G. Anti-nociceptive effects of oxytocin in rats and mice. Neurosci Lett 1994; 170: 153-157.

20. Rojas-Piloni G(1), López-Hidalgo M, Martínez-Lorenzana G, Rodríguez-Jiménez J, Condés-Lara M. GABA- mediated oxytocinergic inhibition in dorsal horn neurons by hypothalamic paraventricular nucleus stimulation. Brain Res 2007; 1137: 69-77.

21. Jiang $C-Y$, Fujita $T$, Kumamoto E. Synaptic modulation and inward current produced by oxytocin in substantia gelatinosa neurons of adult rat spinal cord slices. J Neurophysiol 2014; 111: 991-1007.

22. Mazzuca M, Minlebaev M, Shakirzyanova A, Tyzio R, Taccola G, Janackova S, Gataullina S, Ben-Ari $Y$, Giniatullin R, Khazipov R. Newborn Analgesia Mediated by Oxytocin during Delivery. Front Cell Neurosci 2011; 5: 3.

23. Hobo S, Hayashida KI, Eisenach JC. Oxytocin inhibits the membrane depolarization-induced increase in intracellular calcium in capsaicin sensitive sensory neurons: A peripheral mechanism of analgesic action. Anesth Analg 2012; 114: 442-449.

24. Qiu F, Qiu CY, Cai H, Liu TT, Qu ZW, Yang Z, Li JD, Zhou QY, Hu WP. Oxytocin inhibits the activity of acidsensing ion channels through the vasopressin, V1Areceptor in primary sensory neurons. $\mathrm{Br} J$ Pharmacol 2014; 171: 3065-3076.

25. Meguro Y, Miyano K, Hirayama S, Yoshida Y, Ishibashi $N$, Ogino T, Fujii Y, Manabe S, Eto M, Nonaka $M$ et al. Neuropeptide oxytocin enhances $\mu$ opioid receptor signaling as a positive allosteric modulator. J Pharmacol Sci 2018; 137: 67-75.

26. Holstege JC, Van Dijken H, Buijs RM, Goedknegt H, Gosens T, Bongers CM. Distribution of dopamine immunoreactivity in the rat, cat, and monkey spinal cord. J Comp Neurol 1996; 376: 631-652.

27. Matsumoto M, Hidaka K, Akiho H, Tada S, Okada M, Yamaguchi T. Low stringency hybridization study of the dopamine D4 receptor revealed D4-like mRNA distribution of the orphan seven-transmembrane receptor, APJ, in human brain. Neurosci Lett 1996; 219: 119-122.

28. Tamae A, Nakatsuka T, Koga K, Kato G, Furue $H$, Katafuchi T, Yoshimura M. Direct inhibition of substantia gelatinosa neurones in the rat spinal cord by activation of dopamine D2-like receptors. J Physiol 2005; 568: 243-253.

29. Liu S, Tang Y, Shu H, Tatum D, Bai Q, Crawford J, Xing $Y$, Lobo MK, Bellinger $L$ Kramer $P$ et al. Dopamine receptor D2, but not D1, mediates descending dopaminergic pathway-produced analgesic effect in a trigeminal neuropathic pain mouse model. Pain 2019; 160(2): 334-344

30. Neve KA, Seamans JK, Trantham-Davidson $H$. Dopamine receptor signaling. Journal of Receptors and Signal Transduction. Vol 24. 2004, 165-205.

31. Gao $X$, Zhang $Y$ qiu, Wu $G$ cheng. Effects of dopaminergic agents on carrageenan hyperalgesia after intrathecal administration to rats. Eur J Pharmacol 2001; 418: 73-77. 